\title{
Effect of Farming Practices on Honey Production in Boundary of Gishwati Forest National Park
}

\author{
Nsabimana Prince Alexandre, Nsanzumukiza Martin Vincent*, Uwayo Pacifique, \\ Maniragaba Abias, Segatashya Alexis, Mukasekuru Francoise, Ngirinshuti Henri Jacques
}

Department of Environmental Economics and Natural Resources Management, Faculty of Environmental Studies, University of Lay Adventists of Kigali, Kigali, Rwanda

Email: *nsanzumumartiv@gmail.com

How to cite this paper: Alexandre, N. P., Vincent, N. M., Pacifique, U., Abias, M., Alexis, S., Francoise, M., \& Jacques, N. H. (2020). Effect of Farming Practices on Honey Production in Boundary of Gishwati Forest National Park. Journal of Geoscience and Environment Protection, 8, 107-119. https://doi.org/10.4236/gep.2020.85007

Received: April 6, 2020

Accepted: May 15, 2020

Published: May 18, 2020

Copyright (C) 2020 by author(s) and Scientific Research Publishing Inc. This work is licensed under the Creative Commons Attribution International License (CC BY 4.0)

http://creativecommons.org/licenses/by/4.0/

\begin{abstract}
Pesticides and inorganic fertilizers applied in agriculture are key factors which affect biodiversity, especially bees, butterfly and other pollinators. Therefore, this study assessed the effects of farming practices on honey production in boundary of Gishwati Forest National Park in Rwanda. Survey was conducted to collect data from 2000 year to 2018 year from 51 members grouped in UNICOAPIGI beekeeping and 73 members of JYAMBERE agricultural cooperatives to establish the impact of agriculture practice on honey production. The results showed that the change in agricultural inputs from 2000 to $2018\left(R^{2}=0.901\right)$ resulted in high corn yield and consequently induced honey reduction $\left(\mathrm{R}^{2}=0.75\right)$. The correlation coefficients for pesticides and inorganic fertilizers used in corn production had strong negative effects on honey production $\left\{\gamma_{3}=-0.06\right.$ for chemical fertilizers $\left(X_{3}\right)$ and $\gamma_{4}=-0.42$ for pesticides $\left(\mathrm{X}_{4}\right)$ \}. JYAMBERE Agricultural cooperative with $75.78 \%$ of farmers reported that they used pesticides and inorganic fertilizers in corn production. However, 51 beekeepers grouped in UNICOAPIGI cooperative reported a serious decline of honey production from $27 \mathrm{Kg}$ to $6 \mathrm{Kg}$ of honey per hive after the 2008 year, which is suspected to be mainly the effect from applications of pesticides and fertilizers in corn production. The findings illustrated that the roles of honeybees as pollinator exposed them to toxic, especially pesticides applied in agriculture in boundary of Gishwati national forest reserve, therefore, beekeepers proposed that protection of forests and park is not only sufficient to reach sustainable conservation of bee biodiversity but also requires determining the land use pattern and socio-political factors around the Gishwati forest reserve.
\end{abstract}




\section{Keywords}

Biodiversity, Ecosystem, Agricultural System, Gishwati Forest National Park, Honey Production

\section{Introduction}

The concept of farming practices should focus on honey production (Madhusudan \& Raman, 2003; Kotschi, 2007). In the past 50 years, farming practices undergone major changes from tradition agriculture to the modernization (Rundlöf, Nilsson, \& Smith, 2008). The loss of honey production in agricultural landscapes and in nearby habitats was caused by the removal and fragmentation of habitats (Kremen, Williams, \& Thorp, 2002; Ricketts, 2004) due to agricultural intensification (Chamberlain et al., 2000; Carvell, 2002). Previous research concentrated on crop yields with qualitative analysis and tried to show the major causes for the loss of honey bee colony such as diseases, pesticides and no single pesticide alone has been shown to cause honey bee colony collapse disorder (SanchezBayo \& Goka, 2016) and farming practices on honey production with participatory assessment were unclear and inadequate. During this research, authors did not provide the quantitative analysis through linear model linking both crops (corn) and honey production to pesticides, inorganic fertilizers and organic farming factors which are important variables to discover the evidence behind the reduction of honey yields. However, the previous research illustrated that the average production of honey per hive in Balang'dalalu declined from 20 to $12 \mathrm{~kg}$ due to pesticides without a systematic monitoring (Namwata, Mdundo, \& Malila, 2013), in other research conducted with Johnson et al., illustrated the impact of various pesticides on honey bees, contrary, this study showed that all 51 beekeepers grouped in UNICOAPIGI cooperative reported serious decline of honey production from $27 \mathrm{Kg}$ to $6 \mathrm{Kg}$ of honey yield per hive after the year 2008 as illustrated in Figure 2 and Table 1. In addition, data related to the new pesticides and inorganic fertilizers that cause bee colony mortality and honey reduction are insufficient, some report showed a decline of $45 \%$ of bee colony over the past 60 years in United States of America attributed to organochlorine, carbamate, organophosphorus, and pyrethroid pesticide exposure (Johnson et al., 2010). The report on biological diversity conservation revealed that $75 \%$ of the global ecosystem is exploited by human and only 7000 national protected areas totaling 650 million hectares are less than 5\% of terrestrial areas (Ryan, 1992). According to Western et al. with projection in upcoming twenty years anthropogenic activities will lead to the exhaustion of a 1,000,000 of plant and animal species (Reid \& Miller, 1989; Uwayo et al., 2020). The special concern is about to the rule of thumb which states that if niche declined by $90 \%$ its species will be exhausted by half (Western \& Pearl, 1989). Borron suggested that organic agriculture can help to conserve bees and adjust to climate change for resilience in 
uncertain future (Borron, 2006). According to Sakschewski beekeeping is increasingly becoming an important activity in the world as it provides opportunity for pollination of flowering plants at $75 \%$ to $90 \%$ (both wild and cultivated) by increasing crop yields, income and honey products by ensuring maintenance of habitat and biodiversity (Sakschewski et al., 2016). Pesticides and inorganic fertilizers used in agriculture are among the most investigated and regulated groups of pollutants which affect bee diversity and other pollinators (Lin \& $\mathrm{Hu}$, 2003; Westphal, Steffan-Dewenter, \& Tscharntke, 2003; Zhou et al., 2012; OchoaHueso et al., 2019). Biological diversity in Rwanda extends over the area of 26,338 square kilometers in the national protected areas (Gishwati Forest National Park, Nyungwe Forest National Park, Akagera National Park and National Park of Volcanoes) at the rate of $8 \%$ of the national areas which is less than $16 \%$ at the global level. Even if the small organisms like bees play the crucial role in maintaining the ecosystem and occupy a large portion in agricultural system, the public awareness towards to bee conservation is negligible as the results of the uncontrolled human activities such as application of fertilizers and pesticides in matter of food security. Therefore, this study assessed the effects of farming practices on honey production in boundary of Gishwati Forest National Park in Rwanda, specifically by assessing the effects of pesticides, inorganic fertilizers and organic farming on honey production with intention to restructure strategies to encompass gaps in the matter of increasing honey productivity with respect to the pesticides and inorganic fertilizers application in agriculture.

\section{Material and Methods}

\subsection{Study Area}

The study area is located in Western Province of Rwanda in Rutsiro district in two sectors namely Kigeyo and Ruhango which border Gishwati National Forest Park, Figure 1(a).

In Ruhango sector, Kavumu Cell, Village of Gakeli was identified with key informants of 51 household beekeepers grouped in UNICOAPIGI cooperative and in Kigeyo sector, Rukaragata Cell, Kagondero Village with the key of informants of 73 household farmers grouped in JYAMBERE cooperative. Gishwati Forest National Park is a second mountain forest fragment located in south of the Volcanoes National Park in West of Rwanda ( $\left.1^{\circ} 49^{\prime} \mathrm{S}, 29^{\circ} 22^{\prime} \mathrm{E}\right)$. The significant rainfall throughout the year of $1399 \mathrm{~mm}$ on average, annual average temperature is $17.4^{\circ} \mathrm{C}$ and the temperature decreases for $0.65^{\circ} \mathrm{C}$ for every incremental of $100 \mathrm{~m}$ of altitude. It is part of the Congo Nile Divide forest complex that includes Nyungwe Forest National Park at isolation by $50 \mathrm{Km}$. The community in the study area depend on agricultural activities (Nyandwi \& Mukashema, 2011) with plot size less than a half hectare per household farmer (NISR, 2010) and this show the potentiality of community participation in agricultural and forestry resource exploitation (Chancellor et al., 2012). 


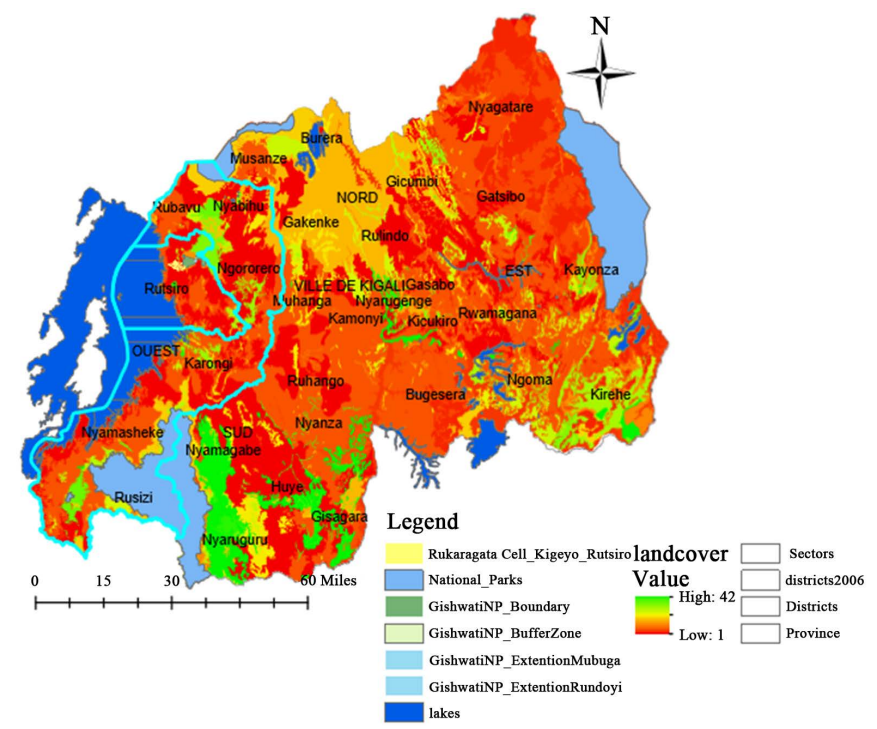

(a)

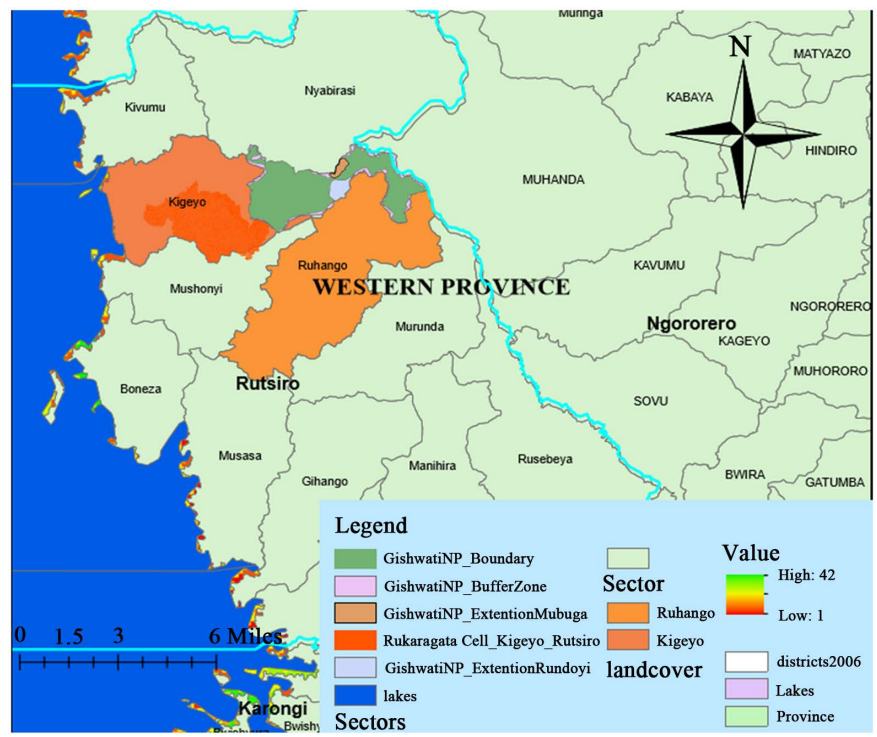

(b)

Figure 1. Map of the study area.

\subsection{Economic Activities around Gishwati Forest National Park}

The economic activities in the study area were composed of agricultural activities with the share of $90 \%$ as the agriculture is the backbone of the economy, tourism services with rate $0.5 \%$, transport services with $1 \%$ and marketing of commodities with $8.5 \%$. Agriculture sector is composed of rearing of animals and cultivation of food crops such as maize, beans, wheat, Irish potatoes and cash crops like tea and vegetables. The agriculture as dominant sector contributed to biodiversity loss due to high rate of inorganic fertilizers and pesticides application. The natural plants to support the 21st century medicine are the other part of interest of economic activity. These economic activities generate the employment at the rate of $79.5 \%$ and this rate is below the district's employment 
rate of $86 \%$ and the reason behind is that in the study area the rate of young professionals in the labor force is low. The household incomes in the study area were led by agriculture with $49 \%$, wages incomes with $38.3 \%$ and other services with $12.7 \%$ (National Institute of Statistics of Rwanda, 2012).

\subsection{Data Collection and Analysis}

In this study, two sectors adjacent to Gishwati Forest national park were identified based on the location of the cooperatives which deal with agriculture and beekeeping. During the data collection, two cooperative working in sectors adjacent to Gishwati Forest national park were selected and provided accurate information. In Ruhango sector, Kavumu Cell, Gakeli Village, all 51 beekeepers grouped in UNICOAPIGI cooperative were identified and Kigeyo Sector, Rukaragata Cell, Kagondero Village, all 73 house hold farmers grouped in JYAMBERE cooperative were selected and involved in data collection. The key informants which were the staff from the sectors, forest manager were also identified. Before conducting the survey, field visit and observations was conducted to better design the questionnaire and identify the main elements of the study including agricultural and beekeeping activities in adjacent to Gishwati Forest National park and in surrounding of the park. The closed and open-ended questions were given to key informants and households grouped in agricultural and beekeeping cooperatives. The data were analyzed with the support of SPSS (Software for Social Sciences). In general, the survey was designed to know the impact of agricultural practices on honey production, and potential impact of pesticides and inorganic fertilizer to bees. The observations on field were conducted several times, in order to identify beepers, agriculturists in surrounding areas and their location, key factors to include such as socio-economic and environment aspect, taking notes and recording data.

\section{Results and Discussion}

\subsection{Effects of Farming Practices on Honey Production}

In Village of Gakeli, Kavumu Cell in Ruhango Sector, about 51 respondents were beekeepers formed UNICOAPIGI cooperative and 73 were farmers grouped in Njyambere agricultural cooperative who use great amount of pesticides, such as Lambdabex, Rocket and inorganic fertilizers, Diamonium Phosphate and Urea to raise corn crops, which affect honey productivity and also the findings of Gary (Gary \& Lorenzen, 1989), illustrated the effect of applying the methamidophos in agriculture at rate of $14 \mathrm{~g} / \mathrm{ha}(0.75 \mathrm{l}$ b/acre $)$ in alfalfa field caused honey reduction. In addition, the 73 farmers identified depended on the farming activities with application of pesticides and inorganic fertilizers to raise the corn yields through JYAMBERE cooperative in Kagondero Village, Rukaragata Cell in Kigeyo and the plot size owned by household farmers was less than 0.5 hectares. With comparison to the District report of National Institute of Statistics of Rwanda (National Institute of Statistics of Rwanda, 2012), about 78\% of population 
are farmers with plot size less than 0.3 hectares and the $49 \%$ of income are generated from agriculture and these results showed the effort of human interaction with the nature in terms of exploitation of the environment and also previous researches reported on the assessment of biodiversity and ecosystem services illustrated that around $25 \%$ of the plant and animal species were threatened with extinction, as the result of anthropogenic activity (Pimm et al., 2006; Díaz et al., 2019; Ji et al., 2019; McGowan et al., 2019; Sol, 2019). The necessity for income between beekeepers and farmers in the study area created the form of land competition where the beekeepers were the most vulnerable due to the decline of honey production resulted from pesticide application. As 73 were household farmers contacted, $75.78 \%$ of them reported that they used pesticides and fertilizers to carry out their agricultural activities and this is in line with the strategies of the district for consolidating the land where about to $80 \%$ of arable land are consolidated with intention of increasing the rate of chemical fertilizers and pesticides used in the District. In addition, 5 staff from local Government and management of the Gishwati Forest national park provided the adequate information on the threats that caused the decline of honey production. They pointed

Table 1. Factors affecting honey production.

\begin{tabular}{|c|c|c|c|c|c|c|c|}
\hline $\begin{array}{l}\text { Observation } \\
\quad \text { (Year) }\end{array}$ & $\begin{array}{c}\text { Honeybee } \\
\text { Production } \\
\quad\left(\mathrm{Y}_{1}\right) \mathrm{Kg}\end{array}$ & $\begin{array}{c}\text { Corn } \\
\text { production } \\
\left(\mathrm{Y}_{2}\right) \mathrm{Kg}\end{array}$ & $\begin{array}{l}\text { Organic } \\
\text { manure } \\
\left(\mathrm{X}_{1}\right) \mathrm{Kg}\end{array}$ & $\begin{array}{c}\text { Local } \\
\text { seeds } \\
\left(\mathrm{X}_{2}\right) \mathrm{Kg}\end{array}$ & $\begin{array}{c}\text { Chemical } \\
\text { fert }\left(\mathrm{X}_{3}\right) \\
\mathrm{Kg}\end{array}$ & $\begin{array}{c}\text { Pesticides } \\
\left(\mathrm{X}_{4}\right) \\
\mathrm{L}\end{array}$ & $\begin{array}{c}\text { Hybrid } \\
\text { maize seed } \\
\left(\mathrm{X}_{5}\right) \mathrm{Kg}\end{array}$ \\
\hline 2000 & 1508 & 243,090 & 197,100 & 1642.5 & 0 & 0 & 0 \\
\hline 2001 & 1467.4 & 246,375 & 203,670 & 1971 & 0 & 0 & 0 \\
\hline 2002 & 1334 & 249,660 & 170,820 & 2299.5 & 0 & 0 & 0 \\
\hline 2003 & 1183.2 & 249,660 & 310,000 & 3000 & 0 & 0 & 0 \\
\hline 2004 & 1334 & 250,317 & 250,000 & 2500 & 0 & 0 & 0 \\
\hline 2005 & 1276 & 252,945 & 302,000 & 3200 & 0 & 0 & 0 \\
\hline 2006 & 1566 & 253,602 & 252,000 & 3000 & 0 & 0 & 0 \\
\hline 2007 & 1160 & 254,259 & 100,000 & 2500 & 0 & 0 & 0 \\
\hline 2008 & 1682 & 254,916 & 100,000 & 2000 & 0 & 0 & 0 \\
\hline 2009 & 945.4 & 255,573 & 100,000 & 1500 & 7784 & 0 & 1000 \\
\hline 2010 & 1044 & 256,230 & 100,000 & 200 & 9855 & 0 & 1400 \\
\hline 2011 & 957 & 257,544 & 100,000 & 100 & 9855 & 19.71 & 1542 \\
\hline 2012 & 638 & 258,858 & 100,000 & 0 & 9855 & 19.71 & 1642.5 \\
\hline 2013 & 580 & 259,515 & 100,000 & 0 & 13140 & 32.85 & 1642.5 \\
\hline 2014 & 745 & 260,172 & 95,600 & 0 & 11000 & 65.7 & 1642.5 \\
\hline 2015 & 464 & 260,829 & 150,000 & 0 & 9855 & 61 & 1708.2 \\
\hline 2016 & 912 & 261,486 & 120,000 & 0 & 9855 & 65.7 & 1708.2 \\
\hline 2017 & 1131 & 262,143 & 150,000 & 0 & 9855 & 98.55 & 1971 \\
\hline 2018 & 596 & 262,800 & 100,000 & 0 & 9856 & 98.55 & 1971 \\
\hline
\end{tabular}


on the usage of pesticides and inorganic fertilizers by focusing on the positive correlation existing between high yield of agricultural crops and inputs. They also provided that beekeeping activities constrained by farming practices because of increasing of food requirements. Table 1 illustrated that after 2008 year, the quantity of inorganic fertilizers and pesticides were started to be applied as a new strategy to raise corn production and in 2000 year the quantity of chemical fertilizers applied was $0 \mathrm{Kg}$ whereas pesticides used was 0 Litres with $1508 \mathrm{Kg}$ of honey yield. In general the quantity of pesticides and inorganic fertilizers increased within timeframe, therefore in 2018 year the quantity reached $9856 \mathrm{Kg}$ for inorganic fertilizers and 98.55 liters for pesticides with shrinking in honey production to $596 \mathrm{Kg}$ (Table 1).

\subsection{Effect of Agricultural Inputs on Corn Production}

In the study area, mechanized agriculture led to high productivity of corn crop since pesticides and chemical fertilizers were used. The classical linear regression model showed the global significant related to all partial regression coefficients for all inputs used in corn production in the study area.

$$
Y_{2 t}=\beta_{0}+1 X_{1 t}+2 X_{2 t}+3 X_{3 t}+4 X_{4 t}+5 X_{5 t}
$$

where " $Y_{2 t}$ " was corn production, " $X_{1 t}$ " was organic manure, " $X_{2 t}$ " was local seeds, " $X_{3 t}$ ” was chemical fertilizer, " $X_{4 t}$ ” was pesticides, " $X_{5 t}$ ” was hybrid maize seeds for all other factors remained constant that might cause a decline in honey production and " $t$ " is range of time in the fluctuation of honey production from 2000 to 2018 (19 years). $\beta_{0}$ was parameter (intercept), whereas $\beta_{1}, \beta_{2}, \beta_{3}, \beta_{4}$ and $\beta_{5}$ were the slope coefficients of the inputs respectively that measure the marginal effect to corn production. The findings showed that the model was of goodness of fit and discovered the root causes of decline in honey production since the $\mathrm{R}^{2}$ of 0.901 was high and close to 1 (Table S1). The reasons behind relate to the fact that about $90.1 \%$ of farming practices had the effects on high corn production which reflect to low honey production.

By farming practices used from 2008 to 2018 year, farmers have been increasing the use of chemical fertilizers and pesticides in agriculture to boost production (Table 1) however this affects the trends of honey production (Table 1). Then "F" observed in Table S1 with observation " $N$ " of 19 years ago of change in corn production was 23.75 calculated value and since it was greater than 0.21 of "F reference (Rohlf \& Sokal, 1995) at the degree of the freedom $d f(5,18)$ for the level of significance of $5 \%$, the truth was that farming practices in the study area was intended to raise corn yield even if it had the potential adverse impact on honey production. As previous researchers stated that farming practices undergone major change with shifting from tradition agriculture to the modernization (Rundlöf, Nilsson, \& Smith, 2008). The shift in farming practices have resulted in higher harvest yields, but also in the decline of bee diversity (Benton, Vickery, \& Wilson, 2003) so for this study the correlation coefficients showed the strong positive relationship of inputs to corn production in the following 
way: $\beta_{2}=5.75$ for local seeds $\left(X_{2}\right), \beta_{3}=0.08$ for chemical fertilizer $\left(X_{3}\right)$ like DAP (Diammonium Phosphate), $\beta_{4}=40.60$ for Pesticides $\left(X_{4}\right)$ such as Lambda bex and rocket, $\beta_{5}=10.16$ for Hybrid maize seed $\left(X_{5}\right)$, Table S2 and the exception was organic manure $\left(\beta_{1}=-0.03\right.$ for $\left.X_{1}\right)$ which was used in minimal quantity since agricultural intensification was introduced in the study area. With comparison to the research of Woyke (Woyke, 1984) on correlation and interactions between population, length of worker life and honey production by honeybees in a temperate region stated the factors that affected honey production such as average daily brood production, length of worker life and individual productivity of workers with correlation coefficients that varied between -0.39 to +0.92 and he continued by showing that this impact affected honey production from $4 \mathrm{Kg}$ to $26 \mathrm{Kg}$ of honey, but the human impacts on honey production were ignored so that this study provided the new knowledge on how the bee colony must be protected as the sole way of increasing honey production and biodiversity conservation by focusing on farming practices.

\subsection{Trend of Honey Production in Period of 19 Years}

The results showed that all 51 beekeepers grouped in UNICOAPIGI cooperative reported a serious declining of honey production after the year 2008 as illustrated in Figure 1. The decline in honey production shrinking from $27 \mathrm{Kg}$ to 6 $\mathrm{Kg}$ of honey per hive and this issue affected beekeepers' livelihoods and the previous reports of Namwata et al. (Namwata, Mdundo, \& Malila, 2013), illustrated that the average production of honey per hive in Balang' dalalu declined from 20 to $12 \mathrm{~kg}$ of honey due to pesticides used in agricultural production. Generally the decline in honey production is a global challenge due to various natural and induced factors (Benuszak, Laurent, \& Chauzat, 2017) and in this study the key informants grouped in JYAMBERE cooperative reported the major factors to the decline of honey production such as the use of inorganic fertilizer with $3.15 \%$, climatic variability with $15.78 \%$, diseases with $5.29 \%$, however, the $75.78 \%$ of farmers reported pesticide (Rocket and Lambdabex). In other research the pesticide was reported by Staveley et al. that the effects of imidacloprid induced the decline of $6 \%-20 \%$ on honey bees which affected honey production (Staveley et al., 2014). The use of the pesticides, inorganic fertilizers and hybrid maize seeds might be the solution for food security but this process posed a threat to bees during the process of pollination such as death of bees, mutation in their genetic materials which resulted to the decline of honey production as illustrated on Figure 2. In addition, the research results revealed that the agricultural intensification caused the decline in honey production in the last period of 19 years in the boundary of Gishwati Forest National Park.

This was the truth that farming practices in the study area had the potential adverse impact on the honey production even if these practices have the effects on high corn production after 2008 year, the quantity of organic manure decreased to reach $100,000 \mathrm{Kg}$ due to agricultural intensification and for local seeds the quantity used felt to $0 \mathrm{Kg}$ as illustrated in the Figure 2. At the same time the 


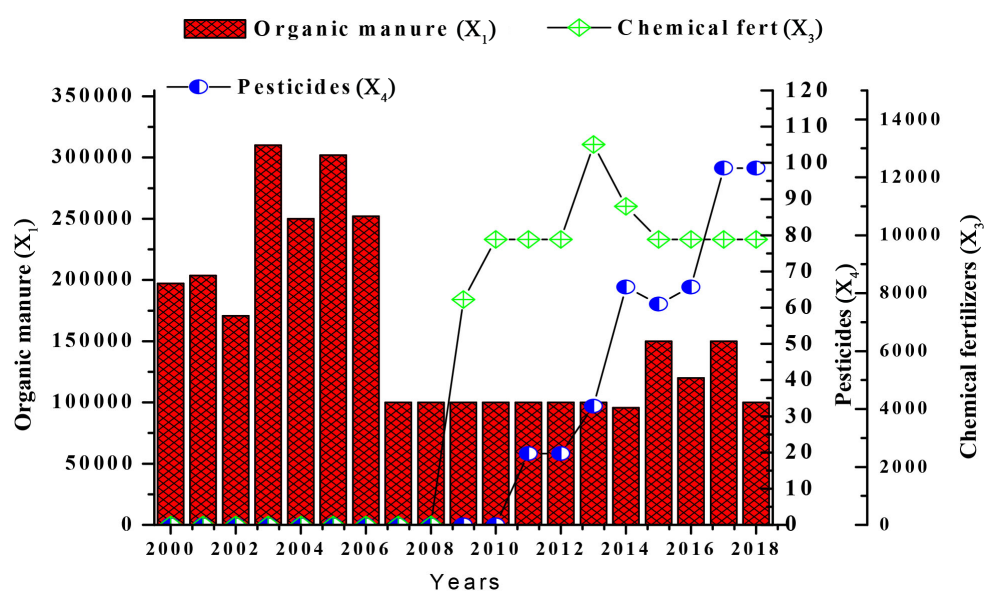

Figure 2. The fluctuation of honey production in period of 19 years from 2000 to 2018.

quantity of chemical fertilizer rose from $0 \mathrm{Kg}$ to $9856 \mathrm{Kg}$ along with pesticides increased from zero liters to 98.55 Litres and resulted in high corn yield $(262,800$ $\mathrm{Kg}$ ) and low honey yield (596 Kg) in 2018 year, Table 1, it is illustrated that before 2008 year with organic manure of $197,100 \mathrm{Kg}, 1642.5 \mathrm{Kg}$ of local seeds, $0 \mathrm{Kg}$ chemical fertilizer, the corn production was very law to medium $(243,090 \mathrm{Kg})$ and high honey productivity $(1508 \mathrm{Kg})$ in 2000 year, Table 1 and Figure 1. It was clear that the study area faced with challenges in honey production. As illustrated in the Table S1 and Table S2, the correlation coefficients also showed the strong negative correlation which indicate that farming practices negatively impacted honey production as follow: $\left\{\gamma_{1}=-0.0001\right.$ for organic manure $\left(X_{1}\right)$ due to agricultural intensification, $\gamma_{2}=-0.12$ for local $\operatorname{seeds}\left(X_{2}\right), \gamma_{3}=-0.06$ for chemical fertilizers $\left(X_{3}\right)$ such as DAP (Diammonium Phosphate and Urea, $\gamma_{4}=$ -0.42 for pesticides $\left(X_{4}\right)$ such as Rocket and Lambda bex and $\gamma_{5}=-0.12$ for Hybrid maize seed $\left.\left(X_{5}\right)\right\}$ to corn production except intercept $\left(\gamma_{0}\right)$ which equals 1722.31 that showed strong positive relationship when other factors remain constants and the $\mathrm{p}$ value is greater than 0.05 level of significant to illustrate that all inputs negatively affected honey production as it is illustrated in Equation (2)

$$
Y_{1 t}=1722.31-0.0001 X_{1 t}-0.12 X_{2 t}-0.06 X_{3}-0.42 X_{4 t}-0.12 X_{5 t}
$$

These field results were not in the same way with the results of Woyke (Woyke, 1984) in his report where the coefficients of regressions indicated that the variation between the number of brood and number adult bees changed from +0.20 to +0.86 to contribute to the production of bee colony of $4 \mathrm{Kg}$ to $26 \mathrm{Kg}$ of honey products. This indicates that other factors surrounding the bee colony that might cause the change in honey production was omitted in Woyke's report. The findings are in line with the reports of Vanlauwe et al. (Vanlauwe et al., 2011) which stated that organic fertilizers, inorganic fertilizers and pesticides in combination raise corn yield for hybrid maize varieties for 17 and $26 \mathrm{Kg} \cdot(\mathrm{Kg} \cdot \mathrm{N})^{-}$, however he presented different adverse impacts which include the loss of biodiversity in the fields. The findings of this research were in conformity with Pimentel et al. which reported that around 2.5 billion $\mathrm{kg}$ of synthetic pesticides are 
used per year in agricultural production, in other industrial products and destroy the biota as a half of million colonies of honey bees are destroyed per year by pesticide (Pimentel et al., 1992; Pretty \& Hine, 2012). Sailer et al. illustrated that exotic species in the domestic countries caused the decline of species for instance about 1500 insect species imported into United States around 17\% (255 species) of them become pests and cost to the States the pesticides for controlling them even though were proved to be important (Sailer, 1983; Williams, 1994; Pimentel et al., 2000).

\section{Conclusion}

This study assessed the effects of farming practices on honey production in boundary of Gishwati Forest National Park, specifically by assessing the effects of pesticides, inorganic fertilizers and organic farming on honey production. This research showed evidence that the effects of farming practices had high positive correlation on corn production and high negative relationships on honey production as all 51 beekeepers grouped in UNICOAPIGI cooperative reported a serious decline of honey production from $27 \mathrm{Kg}$ to $6 \mathrm{Kg}$ of honey per hive after the 2008 year due to pesticide and fertilizer applications in corn production and this issue affected beekeepers' livelihoods. The beekeepers suggested that the protection of forests and park is not sufficient to reach sustainable conservation of the bees' biodiversity but it also requires determining the land use pattern and socio-political factors.

\section{Conflicts of Interest}

The authors declare no conflicts of interest.

\section{References}

Benton, T. G., Vickery, J. A., \& Wilson, J. D. (2003). Farmland Biodiversity: Is Habitat Heterogeneity the Key? Trends in Ecology \& Evolution, 18, 182-188. https://doi.org/10.1016/S0169-5347(03)00011-9

Benuszak, J., Laurent, M., \& Chauzat, M.-P. (2017). The Exposure of Honey Bees (Apis mellifera; Hymenoptera: Apidae) to Pesticides: Room for Improvement in Research. Science of the Total Environment, 587-588, 423-438. https://doi.org/10.1016/j.scitotenv.2017.02.062

Borron, S. (2006). Building Resilience for an Unpredictable Future: How Organic Agriculture Can Help Farmers Adapt to Climate Change. Rome: Food and Agriculture Organization of the United Nations.

Carvell, C. (2002). Habitat Use and Conservation of Bumblebees (Bombus spp.) under Different Grassland Management Regimes. Biological Conservation, 103, 33-49. https://doi.org/10.1016/S0006-3207(01)00114-8

Chamberlain, D. E., Fuller, R. J., Bunce, R. G. H., Duckworth, J. C., \& Shrubb, M. (2000). Changes in the Abundance of Farmland Birds in Relation to the Timing of Agricultural Intensification in England and Wales. Journal of Applied Ecology, 37, 771-788. https://doi.org/10.1046/j.1365-2664.2000.00548.x

Chancellor, R. L., Langergraber, K., Ramirez, S., Rundus, A. S., \& Vigilant, L. (2012). Ge- 
netic Sampling of Unhabituated Chimpanzees (Pan troglodytes schweinfurthii) in Gishwati Forest Reserve, an Isolated Forest Fragment in Western Rwanda. International Journal of Primatology, 33, 479-488. https://doi.org/10.1007/s10764-012-9591-6

Díaz, S., Settele, J., Brondízio, E., Ngo, H., Guèze, M., Agard, J., Arneth, A., Balvanera, P., Brauman, K., \& Butchart, S. (2019). Summary for Policymakers of the Global Assessment Report on Biodiversity and Ecosystem Services of the Intergovernmental SciencePolicy Platform on Biodiversity and Ecosystem Services.

Gary, N. E., \& Lorenzen, K. (1989). Effect of Methamidophos on Honey Bees (Hymenoptera: Apidae) during Alfalfa Pollination. Journal of Economic Entomology, 82, 10671072. https://doi.org/10.1093/jee/82.4.1067

Ji, J., Gao, Y., Lü, Q., Wu, Z., Zhang, W., \& Zhang, C. (2019). China's Early Warning System Progress. Science, 365, 332-332. https://doi.org/10.1126/science.aay4550

Johnson, R. M., Ellis, M. D., Mullin, C. A., \& Frazier, M. (2010). Pesticides and Honey Bee Toxicity-USA. Apidologie, 41, 312-331. https://doi.org/10.1051/apido/2010018

Kotschi, J. (2007). Agricultural Biodiversity Is Essential for Adapting to Climate Change. GAIA-Ecological Perspectives for Science and Society, 16, 98-101. https://doi.org/10.14512/gaia.16.2.8

Kremen, C., Williams, N. M., \& Thorp, R. W. (2002). Crop Pollination from Native Bees at Risk from Agricultural Intensification. Proceedings of the National Academy of Sciences of the United States of America, 99, 16812-16816. https://doi.org/10.1073/pnas.262413599

Lin, C. Y., \& Hu, R. (2003). Students' Understanding of Energy Flow and Matter Cycling in the Context of the Food Chain, Photosynthesis, and Respiration. International Journal of Science Education, 25, 1529-1544. https://doi.org/10.1080/0950069032000052045

Madhusudan, M., \& Raman, T. S. (2003). Conservation as If Biological Diversity Matters: Preservation versus Sustainable Use in India. Conservation and Society, 1, 49-59.

McGowan, P. J., Mair, L., Symes, A., Westrip, J. R., Wheatley, H., Brook, S., Burton, J., King, S., McShea, W. J., \& Moehlman, P. D. (2019). Tracking Trends in the Extinction Risk of Wild Relatives of Domesticated Species to Assess Progress against Global Biodiversity Targets. Conservation Letters, 12, e12588. https://doi.org/10.1111/conl.12588

Namwata, B., Mdundo, K., \& Malila, M. (2013). Potentials and Challenges of Beekeeping Industry in Balang'dalalu Ward, Hanang'District in Manyara, Tanzania. Kivukoni Journal, 1, 75-93.

NISR (2010). Integrated Household Living Conditions Survey.

Nyandwi, E., \& Mukashema, A. (2011). Participatory Geographic Information Systems (P-GIS) for Natural Resource Management and Food Security in Africa: ict4d Article.

Ochoa-Hueso, R., Delgado-Baquerizo, M., King, P. T. A., Benham, M., Arca, V., \& Power, S. A. (2019). Ecosystem Type and Resource Quality Are More Important than Global Change Drivers in Regulating Early Stages of Litter Decomposition. Soil Biology and Biochemistry, 129, 144-152. https://doi.org/10.1016/j.soilbio.2018.11.009

Pimentel, D., Lach, L., Zuniga, R., \& Morrison, D. (2000). Environmental and Economic costs of Nonindigenous Species in the United States. BioScience, 50, 53-66. https://doi.org/10.1641/0006-3568(2000)050[0053:EAECON]2.3.CO;2

Pimentel, D., Stachow, U., Takacs, D. A., Brubaker, H. W., Dumas, A. R., Meaney, J. J., Onsi, D. E., \& Corzilius, D. B. (1992). Conserving Biological Diversity in Agricultural/Forestry Systems. BioScience, 42, 354-362. https://doi.org/10.2307/1311782

Pimm, S., Raven, P., Peterson, A., Şekercioğlu, Ç. H., \& Ehrlich, P. R. (2006). Human 
Impacts on the Rates of Recent, Present, and Future Bird Extinctions. Proceedings of the National Academy of Sciences of the United States of America, 103, 10941-10946. https://doi.org/10.1073/pnas.0604181103

Pretty, J., \& Hine, R. (2012). Pesticide Use and the Environment. In The Pesticide Detox (pp. 23-44). Abingdon-on-Thames: Routledge

Reid, W. V., \& Miller, K. (1989). Keeping Options Alive: The Scientific Basis for Conserving Biodiversity. Washington DC: World Resources Institute.

Ricketts, T. H. (2004). Tropical Forest Fragments Enhance Pollinator Activity in Nearby Coffee Crops. Conservation Biology, 18, 1262-1271. https://doi.org/10.1111/j.1523-1739.2004.00227.x

Rohlf, F. J., \& Sokal, R. R. (1995). Statistical Tables. London: Macmillan.

Rundlöf, M., Nilsson, H., \& Smith, H. G. (2008). Interacting Effects of Farming Practice and Landscape Context on Bumble Bees. Biological Conservation, 141, 417-426. https://doi.org/10.1016/j.biocon.2007.10.011

National Institute of Statistics of Rwanda (2012). The Fourth Population and Housing Census in Rwanda.

Ryan, J. C. (1992). Conserving Biological Diversity. In L. R. Brown, C. Flavin, S. Postel, \& L. Sratke (Eds.), State of the World (pp. 9-26). New York: W. W. Norton.

Sailer, R. I. (1983). History of Insect Introductions. In C. L. Wilson, \& C. L. Graham (Eds.), Exotic Plant Pests and North American Agriculture (pp. 15-38). Cambridge, MA: Academic Press. https://doi.org/10.1016/B978-0-12-757880-4.50007-5

Sakschewski, B., Von Bloh, W., Boit, A., Poorter, L., Peña-Claros, M., Heinke, J., Joshi, J., \& Thonicke, K. (2016). Resilience of Amazon Forests Emerges from Plant Trait Diversity. Nature Climate Change, 6, 1032-1036. https://doi.org/10.1038/nclimate3109

Sanchez-Bayo, F., \& Goka, K. (2016). Impacts of Pesticides on Honey Bees. In E. D. (Ed.), Chambo Beekeeping and Bee Conservation-Advances in Research (pp. 77-97). London: IntechOpen. https://doi.org/10.5772/62487

Sol, J. (2019). Economics in the Anthropocene: Species Extinction or Steady State Economics. Ecological Economics, 165, Article ID: 106392. https://doi.org/10.1016/j.ecolecon.2019.106392

Staveley, J. P., Law, S. A., Fairbrother, A., \& Menzie, C. A. (2014). A Causal Analysis of Observed Declines in Managed Honey Bees (Apis mellifera). Human and Ecological Risk Assessment: An International Journal, 20, 566-591. https://doi.org/10.1080/10807039.2013.831263

Uwayo, P., Nsanzumukiza, V. M., Maniragaba, A., Nsabimana, A. P., \& Akimanizanye, V. (2020). Contribution of Former Poachers for Wildlife Conservation in Rwanda Volcanoes National Park. Journal of Geoscience and Environment Protection, 8, 47-56. https://doi.org/10.4236/gep.2020.84004

Vanlauwe, B., Kihara, J., Chivenge, P., Pypers, P., Coe, R., \& Six, J. (2011). Agronomic Use Efficiency of N Fertilizer in Maize-Based Systems in Sub-Saharan Africa within the Context of Integrated Soil Fertility Management. Plant and Soil, 339, 35-50. https://doi.org/10.1007/s11104-010-0462-7

Western, D., \& Pearl, M. C. (1989). Conservation for the Twenty-First Century. New York: Oxford University Press.

Westphal, C., Steffan-Dewenter, I., \& Tscharntke, T. (2003). Mass Flowering Crops Enhance Pollinator Densities at a Landscape Scale. Ecology Letters, 6, 961-965. https://doi.org/10.1046/j.1461-0248.2003.00523.x

Williams, D. F. (1994). Biology, Impact, and Control of Introduced Species. Boulder, CO: 
Westview Press.

Woyke, J. (1984). Correlations and Interactions between Population, Length of Worker Life and Honey Production by Honeybees in a Temperate Region. Journal of Apicultural Research, 23, 148-156. https://doi.org/10.1080/00218839.1984.11100624

Zhou, J., Xue, K., Xie, J., Deng, Y., Wu, L., Cheng, X., Fei, S., Deng, S., He, Z., \& Van Nostrand, J. D. (2012). Microbial Mediation of Carbon-Cycle Feedbacks to Climate Warming. Nature Climate Change, 2, 106-110. https://doi.org/10.1038/nclimate1331

\section{Supplementary}

Table S1. Regression statistics and ANOVA for corn and honey production.

\begin{tabular}{ccccccccccccc}
\hline \multicolumn{3}{ll}{ ANOVA } & \multicolumn{1}{l}{} & \multicolumn{4}{c}{ Regression Statistics } \\
\hline & df & Residual & Total & F & $\begin{array}{c}\text { Significance } \\
\text { F }\end{array}$ & $\begin{array}{c}\text { Multiple } \\
\text { R }\end{array}$ & $\begin{array}{c}\text { R } \\
\text { Square }\end{array}$ & $\begin{array}{c}\text { Adjusted } \\
\text { R Square }\end{array}$ & $\begin{array}{c}\text { Standard Error } \\
\text { Observations }\end{array}$ \\
\hline Regression for corn production & 5 & 13 & 18 & 23.75 & $4.10248 \mathrm{E}-06$ & 0.949 & 0.90 & 0.86 & 2059.31 & 19 \\
Regression for honey production & 5 & 13 & 18 & 7.87 & $4.10248 \mathrm{E}-06$ & 0.86 & 0.75 & 0.65 & 212 & 19 \\
\hline
\end{tabular}

Table S2. Coefficients values in corn and honey production.

\begin{tabular}{|c|c|c|c|c|c|c|}
\hline & \multicolumn{3}{|c|}{ Values in corn production } & \multicolumn{3}{|c|}{ Values in honey production } \\
\hline & Coefficients & t Stat & P-value & Coefficients & t Stat & P-value \\
\hline Intercept & $242,899.82$ & 76.61 & $1.19 \mathrm{E}-18$ & 1722.31 & 5.27 & 0.00 \\
\hline Organic manure $\left(\mathrm{X}_{1}\right)$ & -0.03 & -2.95 & 0.01 & -0.00 & -0.13 & 0.89 \\
\hline local seeds $\left(\mathrm{X}_{2}\right)$ & 5.75 & 3.93 & 0.001 & -0.12 & -0.80 & 0.43 \\
\hline Chemical fertilizer $\left(\mathrm{X}_{3}\right)$ & 0.08 & 0.13 & 0.89 & -0.06 & -1.06 & 0.30 \\
\hline Pesticides $\left(\mathrm{X}_{4}\right)$ & 40.60 & 1.20 & 0.24 & -0.42 & -0.12 & 0.90 \\
\hline Hybrid maize seed $\left(\mathrm{X}_{5}\right)$ & 10.164 & 2.11 & 0.05 & -0.12 & -0.25 & 0.80 \\
\hline
\end{tabular}

